\title{
ANALISIS KEPEMILIKAN INSTITUSIONAL,STRUKTUR MODAL DAN RETURN ON ASET ( ROA ) TERHADAP NILAI PERUSAHAAN MANUFAKTUR YANG TERDAFTAR DI BEI PERIODE 2015 -2017
}

\author{
Yuslinda Nasution \\ Dosen Tetap Program S1 Jurusan Manajemen Fakultas Ekonomi Universitas Satya Negara Indonesia \\ email:n.yuslinda@yahoo.com
}

\begin{abstract}
ABSTRAK
Penelitian ini bertujuan untuk mengetahui pengaruh Kepemilikan Intitusional,Struktur Modal dan ROA sebagai variabel independent sedang Nilai Perusahaan sebagai variabel dependent. Sampel yang digunakan dalam penelitian ini adalah seluruh perusahaan manufaktur yang terdaftar di Bursa Efek Indonesia selama periode tahun 2015 sampai dengan 2017. Metode pengambilan sampel yang digunakan adalah purposive sampling, dimana pengambilan sampel dilakukan berdasarkan kriteria tertentu. Metode statistik yang digunakan dalam penelitian ini adalah metode regresi berganda. Hasil penelitian ini menunjukkan Kepemilikan Institusional,Struktur Modal dan ROA secara simultan berpengaruh terhadap Nilai Perusahaan ( PBV ), secara parsial variabel Kepemilikan Institusional dan struktur Modal ( DER ) tidak berpengaruh terhadap Nilai Perusahaan ( PBV), variabel ROA berpengaruh terhadap Nilai Perusahaan ( PBV).
\end{abstract}

Kata Kunci : Rasio keuangan, PBV,Kepemilikan Institusional, DER,ROA

\section{PENDAHULUAN}

\subsection{Latar Belakang Penelitian}

Persaingan dunia bisnis di era globalisasi semakin kompetitif, salah satu cara agar perusahaan tetap bisa bertahan dalam persaingan adalah dengan meningkatkan nilai perusahaannya. Perusahaan yang mampu bertahan dalam persaingan dan terus berkembang, akan mempunyai nilai yang tinggi dimata investor. Nilai perusahaan menjadi konsep yang penting bagi investor sebagai indikator penilaian kinerja perusahaan secara keseluruhan. Semakin tinggi penilaian investor terhadap suatu perusahaan, maka harga saham perusahaan tersebut juga akan semakin meningkat (Salvator, 2005). Semakin tinggi harga saham semakin tinggi pula nilai perusahaan. Nilai perusahaan yang tinggi akan membuat pasar percaya tidak hanya pada kinerja perusahaan saat ini namun juga pada prospek perusahaan dimasa yang akan datang.

Nilai perusahaan yang dibentuk melalui indikator pasar saham, sangat dipengaruhi oleh peluang-peluang investasi. Pengeluaran investasi memberikan sinyal positif dari investasi kepada manajer tentang pertumbuhan perusahaan di masa yang akan datang, sehingga meningkatkan harga saham sebagai indikator nilai perusahaan. Harga saham yang tinggi membuat nilai perusahaan juga tinggi (Brealey et al, 2007:46).

Menurut Husman (2000), Nilai perusahaan merupakan harga yang bersedia dibayar oleh calon pembeli apabila perusahaan tersebut dijual. Nilai perusahaan pada perusahaan publik umumnya dikaitkan dengan harga saham yang beredar dipasar, karna harga pasar saham 
menunjukkan penilaian sentral di semua pelaku pasar yang merupakan barometer kinerja perusahaan yang digunakan sebagai sarana apresiasi bagi investor.

Menurut Soliha dan Taswan (2002), Nilai perusahaan juga lazin diindikasikan dengan Price To Book Value (PBV). PBV merupakan rasio untuk menentukan nilai intrinsik saham yang akan mempengaruhi keputusan investor untuk membeli atau menjual saham. PBV menunjukkan seberapa jauh suatu perusahaan mampu menciptakan nilai perusahaan yang relatif terhadap jumlah modal yang di investasikan. Semakin tinggi rasio PBV, maka dapat diartikan bahwa kepercayaan investor terhadap perusahaan juga semakin tinggi atau dengan kata lain akan membuat pasar percaya atas prospek perusahaan kedepan (Wirawati, 2008).

Struktur kepemilikan saham perusahaan sangat mempengaruhi kelangsungan perusahaan yang selanjutnya mempunyai pengaruh pada kinerja dan kualitas perusahaan untuk mencapai visi suatu perusahaan ialah memaksimalkan nilai perusahaan. Struktur kepemilikan merupakan presentase kepemilikan saham terhadap keseluruhan jumlah saham yang dimiliki perusahaan. Presentase terdiri dari kepemilikan institusional, kepemilikan manajerial dan publik. Kepemilikan institusional adalah kepemilikan saham yang dimiliki oleh institusi lain seperti perusahaan asuransi, perusahaan investasi, bank dan pemerintah. Kepemilikan institusional memiliki kewenangan dalam memonitor manajemen dan adanya kepemilikan institusional dapat mendorong peningkatan pengawasan yang lebih optimal sehingga dapat meningkatkan nilai perusahaan (Tarjo Sholekah, 2014). Dengan bertambah tingginya tingkat kepemilikan institusional, maka mampu menciptakan pengawasan yang besar sehingga perilaku opportunistic manajer terhalangi. Menurut Permanasari (2010) menyatakan bahwa besarnya tingkat kepemilikan institusi keuangan mengakibatkan kekuatan suara dan dorongan untuk mengoptimalkan nilai perusahaan semakin besar pula. Adanya kepemilikan saham oleh investor institusional maka proses monitoring akan berjalan lebih efektif sehingga dapat mengurangi tindakan manajerial dalam hal melakukan manajemen laba sehingga dapat merugikan kepentingan pihak tertentu (stakeholder).

Struktur modal merupakan salah satu keputusan pendanaan yang sangat penting bagi kesejahteraan perusahaan. Kesalahan dalam pengambilan keputusannya dapat meningkatkan risiko financial distress yang menyebabkan perusahaan mengalami kebangkrutan (Wardianto, 2012). Menurut Husnan dan Pudjiastuti (2006: 263) struktur modal terbaik adalah struktur modal yang dapat memaksimumkan nilai perusahaan atau harga saham, sehingga perusahaan yang memiliki struktur modal yang baik akan mampu meningkatkan nilai perusahaan. Struktur modal mencerminkan bagaimana perusahaan mendanai kegiatan operasinya.

Struktur modal merupakan perbandingan antara utang dengan ekuitas, struktur modal merupakan masalah penting dalam keputusan belanja (Yasa, 2013). Teori MM (Modigliani dan Miller) menyatakan bahwa peningkatan utang dapat meningkatkan nilai perusahaan apabila belum mencapai titik optimalnya, hal ini diperkuat oleh teori trade-off yang menjelaskan bahwa penggunaan utang dapat mengurangi beban pajak dan biaya agensi perusahaan (Brigham dan Houston, 2001).

Profitabilitas adalah kemampuan perusahaan dalam mengelola sumber daya perusahaan untuk menghasilkan laba perusahaan. Menurut Fama dan French dalam Prapaska dan Mutmainah (2012) Nilai perusahaan ditentukan oleh profitabilitas perusahaan. Profitabilitas merupakan suatu indikator kinerja yang dilakukan oleh manajemen perusahaan dalam mengelola kekayaan perusahaan yang ditunjukkan oleh laba yang dihasilkan perusahaan. Optimalisasi nilai perusahaan 
yang merupakan tujuan perusahaan juga dapat dicapai melalui pelaksanaan fungsi manajemen keuangan, dalam hal ini satu keputusan keuangan yang diambil akan mempengaruhi keputusan keuangan lainnya dan berdampak pada nilai perusahaan.

\section{Tabel 1.1}

Perusahaan Manufaktur di BEI yang Mengalami Kenaikan dan Penurunan Nilai Perusahaan (PBV) Tiga Tahun Terakhir (2015-2017).

\begin{tabular}{|l|l|l|l|}
\hline PERUSAHAAN & $\mathbf{2 0 1 5}$ & $\mathbf{2 0 1 6}$ & $\mathbf{2 0 1 7}$ \\
\hline Gudang Garam Tbk & 2.78 & 3.27 & 4.04 \\
\hline $\begin{array}{l}\text { Inti Keramik Alam } \\
\text { Asri Industri Tbk }\end{array}$ & 1.31 & 0.50 & -0.69 \\
\hline Barito Pasific Tbk & 0.06 & 0.57 & 1.15 \\
\hline Sekar Bumi Tbk & 2.57 & 1.65 & 1.23 \\
\hline
\end{tabular}

Sumber : http://www.idx.co.id//, (data diolah)

Dari tabel 1.1 diatas dapat terlihat adanya fenomena kenaikan dan penurunan nilai perusahaan (PBV) terus menerus selama tiga tahun berturut-turut (2015-2017) di beberapa perusahaan manufaktur yang terdaftar di Bursa Efek Indonesia.

Untuk mengetahui mengapa nilai perusahaan pada tabel 1.1 tersebut mengalami kenaikan dan penurunan terus menerus maka perlu diketahui faktor-faktor apa saja yang mempengaruhi nilai perusahaan.

Secara teori dan didukung oleh beberapa hasil penelitian bahwa ada beberapa faktor yang mempengaruhi nilai perusahaan yaitu Kepemilikan Institusional (KI), Struktur Modal dengan indikator Debt to Equity Rasio (DER), dan Return On Asset (ROA).

Tabel 1.2

Data Nilai Perusahaan, Kepemilikan Institusional, Struktur Modal, dan Profitabilitas Beberapa Perushaan Manufaktur di BEI Periode Tahun 2015 - 2017.

\begin{tabular}{|l|l|l|l|l|}
\hline \multirow{2}{*}{ Perusahaan } & \multirow{2}{*}{ Variabel } & \multicolumn{3}{|l|}{ Tahun } \\
\cline { 3 - 5 } & & $\mathbf{2 0 1 5}$ & $\mathbf{2 0 1 6}$ & $\mathbf{2 0 1 7}$ \\
\hline \multirow{4}{*}{$\begin{array}{l}\text { Gudang Garam } \\
\text { Tbk }\end{array}$} & PBV & 2.78 & 3.27 & 4.04 \\
\cline { 2 - 5 } & KI & $75.55 \%$ & $75.55 \%$ & $75.55 \%$ \\
\cline { 2 - 5 } & DER & 0.67 & 0.59 & 0.58 \\
\cline { 2 - 5 } & ROA & 10.16 & 10.60 & 11.62 \\
\hline \multirow{3}{*}{$\begin{array}{l}\text { Inti Keramik Asri } \\
\text { Industri Tbk }\end{array}$} & KBV & 1.31 & 0.50 & -0.69 \\
\cline { 2 - 5 } & KER & $77.42 \%$ & $77.42 \%$ & $77.42 \%$ \\
\cline { 2 - 5 } & ROA & -27.92 & -54.85 & -18.96 \\
\hline \multirow{2}{*}{$\begin{array}{l}\text { Barito Pasific } \\
\text { Tbk }\end{array}$} & PBV & 0.06 & 0.57 & 1.15 \\
\cline { 2 - 5 } & KI & $70.21 \%$ & $70.47 \%$ & $1.91 \%$ \\
\hline
\end{tabular}




\begin{tabular}{|l|l|l|l|l|}
\hline & DER & 0.88 & 0.77 & 0.81 \\
\cline { 2 - 5 } & ROA & 0.23 & 10.88 & 7.68 \\
\hline \multirow{3}{*}{$\begin{array}{l}\text { Sekar Bumi } \\
\text { Tbk }\end{array}$} & PBV & 2.57 & 1.65 & 1.23 \\
\cline { 2 - 5 } & KI & $80.48 \%$ & $80.61 \%$ & $82.80 \%$ \\
\cline { 2 - 5 } & DER & 1.22 & 1.72 & 0.59 \\
\cline { 2 - 5 } & ROA & 5.25 & 2.25 & 1.59 \\
\hline
\end{tabular}

Sumber : http://www.idx.co.id/, (data diolah)

Pada Tabel 1.2 Gudang Garam Tbk dapat dilihat bahwa rata-rata variabel berfluktuasi setiap tahunnya. Pada variabel DER juga terjadi ketidaksesuaian dengan teori dimana pada tahun 2015-2016 DER mengalami penurunan sebesar 0,08 sementara PBV naik sebesar 0,49.

Pada tabel 1.2 Inti Keramik Alam Asri Industri Tbk tahun 2016-2017, ROA mengalami kenaikan tapi masih berada di zona merah, kenaikan ada sebesar 35,89 sementara PBV mengalami penurunan sebesar 1,19 artinya juga tidak sesuai dengan teori yang ada.

Pada tabel 1.2 Barito Pasific Tbk tahun 2016-2017, Kepemilikan institusional turun signifikan sebesar $68,56 \%$ sementara PBV naik sebesar 0,58 dan hal ini tidak sesuai dengan teori yang ada. DER pada tahun 2015-2016 mengalami penurunan sebesar 0,11 tetapi PBV mengalami kenaikan sebesar 0,51 dan kondisi ini juga tidak sesuai dengan teori yang ada. ROA pada tahun 2016-2017 mengalami penurunan sebesar 3,20 sementara PBV nya mengalami kenaikan sebesar 0,58 . Kondisi ini juga tidak sesuai dengan teori yang ada dimana pada saat ROA turun maka PBV nya juga akan mengalami penurunan.

Pada tabel 1.2 Sekar Bumi Tbk tahun 2015-2016 KI mengalami kenaikan sebesar 0,13 sementara PBV nya mengalami penurunan sebesar 0,92 dan ketika KI pada tahun berikutnya (2017) mengalami kenaikan sebesar 2,19 tetapi PBV nya mengalami penurunan sebesar 0,92. Kondisi ini tidak sesuai dengan teori yang ada dimana pada saat KI mengalami kenaikan maka PBV juga ikut naik dan juga sebaliknya, DER pada tahun 2015-2016 naik sebesar 0,5 sementara PBV turun sebesar 0,92. Kondisi ini juga tidak sesuai dengan teori yang ada.

\subsection{Penelitian Terdahulu}

Penelitian sebelumnya terkait faktor-faktor yang mempengaruhi nilai perusahaan telah banyak dilakukan. Berikut ini adalah penelitian sebelumnya yang terkait dengan faktor yang mempengaruhi nilai perusahaan:

Tabel 1.3

Penelitian Terdahulu

\begin{tabular}{|c|c|c|c|}
\hline Variabel & Penelitian & Tahun & Hasil Penelitian \\
\hline $\begin{array}{l}\text { Kepemilikan } \\
\text { Institusional }\end{array}$ & $\begin{array}{l}\text { Sally Malva } \\
\text { Octavia }\end{array}$ & 2017 & \begin{tabular}{lrr} 
Kepemilikan & \multicolumn{2}{c}{ Institusional } \\
berpengaruh & positif & secara \\
signifikan & terhadap & nilai \\
perusahaan & &
\end{tabular} \\
\hline
\end{tabular}




\begin{tabular}{|c|c|c|c|}
\hline & Elva Nuraina & 2012 & $\begin{array}{l}\text { Kepemilikan Institusional tidak } \\
\text { berpengaruh signifikan terhadap } \\
\text { Nilai Perusahaan }\end{array}$ \\
\hline & Lestari & 2017 & $\begin{array}{l}\text { Kepemilikan Institusional } \\
\text { berpengaruh positif terhadap nilai } \\
\text { perusahaan }\end{array}$ \\
\hline & Praditia & 2010 & $\begin{array}{lcc}\begin{array}{l}\text { Kepemilikan } \\
\text { berpengaruh } \\
\text { perusahaan }\end{array} & \begin{array}{c}\text { Institusional } \\
\text { terhadap }\end{array} & \text { nidak } \\
\text { nilai }\end{array}$ \\
\hline & Dewi, dkk & 2012 & $\begin{array}{l}\text { DER berpengaruh signifikan } \\
\text { terhadap nilai perusahaan }\end{array}$ \\
\hline & Lestari & 2017 & $\begin{array}{l}\text { DER tidak berpengaruh } \\
\text { signifikan terhadap nilai } \\
\text { perusahaan }\end{array}$ \\
\hline DER & $\begin{array}{l}\text { Topowijono } \\
\text { dan } \\
\text { Sulasmiyati }\end{array}$ & 2014 & $\begin{array}{l}\text { DER berpengaruh terhadap nilai } \\
\text { perusahaan }\end{array}$ \\
\hline & Budi Hartono & 2016 & $\begin{array}{l}\text { DER tidak berpengaruh dan tidak } \\
\text { signifikan terhadap nilai } \\
\text { perusahaan }\end{array}$ \\
\hline & $\begin{array}{l}\text { Dwi } \\
\text { Ayuningtyas } \\
\text { dan Kurnia } \\
\end{array}$ & 2013 & $\begin{array}{l}\text { ROA berpengaruh positif } \\
\text { terhadap PBV }\end{array}$ \\
\hline & Madinatul & 2016 & $\begin{array}{l}\text { ROA tidak memiliki pengaruh } \\
\text { terhadap PBV }\end{array}$ \\
\hline ROA & $\begin{array}{l}\text { Umi } \\
\text { Mardiyati, } \\
\text { Gatot Nazir } \\
\text { Ahmad, Dan } \\
\text { Ria Putri }\end{array}$ & 2012 & $\begin{array}{lrr}\text { ROA } & \text { berpengaruh } & \text { positif } \\
\text { signifikan } & \text { terhadap } & \text { nilai } \\
\text { perusahaan } & & \end{array}$ \\
\hline & Hermawan & 2014 & $\begin{array}{lcr}\text { ROA tidak } & \text { berpengaruh } & \text { secara } \\
\text { signifikan } & \text { terhadap } & \text { nilai } \\
\text { perusahaan } & & \end{array}$ \\
\hline
\end{tabular}

Sumber : Diolah Peneliti

Penelitian sebelumnya terkait faktor-faktor yang mempengaruhi nilai perusahaan telah banyak dilakukan. Berikut ini adalah penelitian sebelumnya yang terkait dengan faktor yang mempengaruhi nilai perusahaan.

Penelitian Sally Malva Octavia (2017) dan Lestari (2017) menyatakan bahwa kepemilikan institusional berpengaruh positif secara signifikan terhadap nilai perusahaan, sedangkan pada penelitian Elva Nuraina (2012) dan Praditia (2010) menyatakan bahwa kepemilikan institusional tidak berpengaruh terhadap nilai perusahaan.

Dari penelitian Dewi, dkk (2012) dan Topowijono dan Sulasmiyati (2014) menunjukkan bahwa DER berpengaruh dan signifikan terhadap nilai perusahaan, sementara pada penelitian Lestari (2017) dan Budi Hartono (2016) menyatakan bahwa DER tidak berpengaruh dan tidak signifikan terhadap nilai perusahaan. 
Penelitian Dwi Ayuningtyas dan Kurnia (2013) dan Umi Mardiyati, Gatot Nazir Ahmad, Dan Ria Putri (2012) menyatakan bahwa ROA berpengaruh positif terhadap nilai perusahaan, sedangkan menurut Madinatul (2016) dan Hermawan (2014) menyatakan bahwa ROA tidak memiliki pengaruh terhadap nilai perusahaan.

Maka berdasarkan fenomena yang ada dan masih adanya perbedaan hasil penelitian sebelumnya, penelitian selanjutnya layak dilakukan. Peneliti tertarik melakukan penelitian dengan judul "ANALISIS KEPEMILIKAN INSTITUSIONAL, STRUKTUR MODAL, DAN ROA TERHADAP NILAI PERUSAHAAN MANUFAKTUR YANG TERDAFTAR DI BURSA EFEK INDONESIA PERIODE TAHUN 2015-2017"

\section{KERANGKA PENELITIAN TEORITIS DAN HIPOTESIS Pengertian Nilai Perusahaan}

Nilai perusahaan merupakan persepsi investor terhadap perusahaan, yang sering dikaitkan dengan harga saham. Nilai perusahaan yang dibentuk melalui indikator pasar saham, sangat dipengaruhi oleh peluang-peluang investasi. Pengeluaran investasi memberikan sinyal positif dari investasi kepada manajer tentang pertumbuhan perusahaan di masa yang akan datang, sehingga meningkatkan harga saham sebagai indikator nilai perusahaan. Harga saham yang tinggi membuat nilai perusahaan juga tinggi (Brealey et al, 2007:46).

Menurut Noerirawan ( 2012 ), nilai perusahaan merupakan kondisi yang telah dicapai suatu perusahaan sebagai gambaran dari kepercayaan masyarakat terhadap perusahaan setelah melalui suatu proses kegiatan selama beberapa tahun,yaitu sejak perusahaan itu didirikan sampai saat ini.

\section{Beberapa Indikator yang Dapat Digunakan untuk Mengukur Nilai Perusahaan antara lain:}

\section{a. Price Earning Ratio (PER)}

Price earning ratio menunjukkan berapa banyak jumlah uang yang rela dikeluarkan oleh para investor untuk membayar setiap dolar laba yang dilaporkan (Brigham dan Houston, 2006:110).

\section{b. Tobin's $Q$}

Tobin's $Q$ ditemukan oleh seorang pemenang hadiah nobel dari Amerika Serikat yaitu James Tobin. Tobin's $Q$ adalah nilai pasar dari aset perusahaan dengan biaya penggantinya. Menurut konsepnya, rasio Q lebih unggul daripada rasio nilai pasar terhadap nilai buku karena rasio ini fokus pada berapa nilai perusahaan saat ini secara relatif terhadap berapa biaya yang dibutuhkan untuk menggantinya saat ini. Dalam praktiknya, rasio Q sulit untuk dihitung dengan akurat karena memperkirakan biaya penggantian atas aset sebuah perusahaan bukanlah suatu pekerjaan yang mudah (Margaretha, 2014:20).

\section{c. Price to Book Value (PBV)}

Komponen penting lain yang harus diperhatikan dalam analisis kondisi perusahaan adalah Price to Book Value (PBV) yang merupakan salah satu variabel yang dipertimbangkan seorang investor dalam menentukan saham mana yang akan dibeli. Untuk perusahaan-perusahaan yang berjalan dengan baik, umumnya rasio ini mencapai diatas satu, yang menunjukkan bahwa 
nilai pasar saham lebih besar dari nilai bukunya. Semakin besar rasio PBV semakin tinggi perusahaan dinilai oleh para pemodal relatif dibandingkan dengan dana yang telah ditanamkan di perusahaan.

Price to book value yang tinggi akan membuat pasar percaya atas prospek perusahaan kedepan. Hal itu juga yang menjadi keinginan para pemilik perusahaan, sebab nilai perusahaan yang tinggi mengindikasikan kemakmuran pemegang saham juga tinggi. Menurut (Brigham dan Houston, 2006:112).

\section{Pengertian Kepemilikan Institusional}

Baridwan (2004) mendefinisikan kepemilikan institusional sebagai proporsi saham yang dimiliki oleh suatu lembaga atau institusi pada akhir tahun. Kepemilikan institusional adalah proporsi saham yang dimiliki institusional pada akhir tahun yang diukur dalam persentase (\%). Institusi biasanya dapat menguasai mayoritas saham karena mereka memiliki sumber daya yang lebih besar dibandingkan dengan pemegang saham lainnya.

\section{Pengertian Struktur Modal}

Menurut Van Horne, Markowicz (2005) Struktur modal adalah bauran atau proporsi pendanaan permanen jangka panjang perusahaan yang diwakili oleh utang, saham preferen dan ekuitas saham biasa.

Menurut Brigham dan Houston (2011) struktur modal yang optimal merupakan struktur modal yang akan memaksimalkan harga saham perusahaan, dan struktur ini pada umumnya meminta rasio utang yang lebih rendah daripada rasio yang memaksimalkan Earnings Per Share (EPS) yang diharapkan.

\section{Teori Struktur Modal}

Beberapa teori yang berkaitan dengan keputusan struktur modal antara lain:

\section{a. Teori Pertukaran (Trade-Off Theory)}

Teori struktur modal yang menyatakan bahwa perusahaan menukar manfaat pajak dari pendanaan utang dengan masalah yang ditimbulkan oleh potensi kebangkrutan. Teori trade-off memperkirakan bahwa rasio utang sasaran akan bervariasi antara perusahaan satu dengan yang lain

\section{b.Pecking Order Theory}

Pecking order theory adalah teori alternatif yang dapat menjelaskan mengapa perusahaan yang menguntungkan meminjam jumlah uang yang lebih sedikit. Teori ini berdasarkan asumsi asimetris dimana manajer lebih banyak mengetahui informasi tentang profitabilitas dan prospek perusahaan dibandingkan dengan investor.

Perusahaan menyukai pendanaan internal, karena dana ini terkumpul tanpa mengirimkan sinyal sebaliknya yang dapat menurunkan harga saham.

Jika dana eksternal dibutuhkan, perusahaan menerbitkan utang lebih dahulu dan hanya menerbitkan ekuitas sebagai pilihan terakhir (Brealey dkk, 2008). 


\section{c. Agency Theory (Teori Keagenan)}

Teori keagenan diajukan oleh Michael C. Jensen dan William H. Meckling pada tahun 1976. Teori ini merupakan hubungan keagenan yaitu hubungan antara pemegang saham (principal) dengan manajer (agent) yang diberi kekuasaan untuk membuat keputusan.

Metode yang dapat digunakan untuk mengurangi konflik keagenan antara lain, pertama dengan pengendalian eksternal atau mekanisme motivasional, dengan peningkatan kepemilikan manajer dalam perusahaan Jensen dan Meckling dalam Rahayu (2005). Kedua dengan menggunakan peningkatan penggunaan utang (internal control) yang dimaksudkan untuk menyelaraskan kepentingan kedua belah pihak sekaligus memberikan tanggung jawab lebih kepada manajer untuk selalu melakukan pekerjaannya sesuai dengan tujuan yang ingin dicapai perusahaan yaitu memaksimalkan kesejahteraan pemegang saham.

Teori Sinyal

Modigliani dan Miller berasumsi bahwa setiap orang baik investor maupun manajer memiliki informasi yang sama tentang prospek suatu perusahaan. Hal ini disebut dengan informasi simetris (symmetric information). Namun pada kenyataannya manajer sering kali memiliki informasi yang lebih baik dibandingkan dengan investor. Hal ini disebut sebagai informasi asimetris (asymmetric information), yang akan berpengaruh penting terhadap struktur modal.

\section{Pengertian Return On Asset ( ROA )}

Return on Assets atau dalam bahasa Indonesia sering disebut dengan Tingkat Pengembalian Aset adalah rasio profitabilitas yang menunjukan persentase keuntungan (laba bersih) yang diperoleh perusahaan sehubungan dengan keseluruhan sumber daya atau rata-rata jumlah aset. Dengan kata lain, Return on Assets atau sering disingkat dengan ROA adalah rasio yang mengukur seberapa efisien suatu perusahaan dalam mengelola asetnya untuk menghasilkan laba selama suatu periode.

Pengertian Return on Asset (ROA) menurut (Mamduh M. Hanafi, $\quad$ 2007:159): "Return on Asset (ROA) mengukur kemampuan perusahaan menghasilkan laba dengan menggunakan total aset (kekayaan) yang dipunyai perusahaan setelah disesuaikan dengan biayabiaya untuk mendanai aset tersebut.

Rumus yang digunakan untuk perhitungan return on asset (ROA) adalah sebagai berikut (Martono dan Harjito, 2012:61):

$$
\mathrm{ROA}=\frac{\text { Laba Bersih (EAT) }}{\text { Total Asset }} x 100 \%
$$

\section{Aksioma Dalam Manajemen Keuangan}

Aksioma dalam manajemen keuangan. Aksioma memberikan pengertian bahwa pernyataan-pernyataan yang memiliki dasar kebenaran/ terbukti kebenarannya, berikut Aksioma Manajemen Keuangan:

1. Risk-return trade-off

Risk-return trade-off merupakan pernyataan yang menunjukkan adanya pertukaran antara resiko dan return, suatu tuntutan konsekuensi dari sebuah sebab. Prinsipnya 
adalah semakin tinggi resiko suatu pekerjaan maka return yang diperoleh mestinya harus semakin besar.

2. Time value of money (Nilai waktu uang)

Bahwa menerima sejumlah uang di waktu sekarang lebih baik dari pada menerimanya dengan jumlah yang sama di masa yang akan datang. Hal ini berkaitan dengan nilai uang yang semakin lama semakin menurun akibat terjadinya inflasi. Penurunan nilai uang inilah yang menjadi salah satu dasar munculnya bunga dalam perbankan sebagai bentuk antisipasi agar nilai uang yang akan datang tidak menurun dari nilai uang sekarang.

3. Cash-not profit - is king

Dalam pepatah lama dikatakan "Profit is queen, but cash is king". Dalam banyak kasus, para pengusaha sering menjadi repot mengurus bisnisnya dikarenakan kesulitan keuangan di tahun berikutnya, padahal, menurut catatannya, laba yang diperoleh selalu meningkat. Tetapi setelah diteliti ternyata keuntungan yang diperoleh perusahaannya hampir semua dalam bentuk piutang yang tingkat likuiditasnya tentu kalah dibandingkan dengan kas. Kesulitan keuangan yang dialamai oleh banyak pebisnis salah satunya disebabkan karena mereka terlalu fokus pada laba, dan mengabaikan aliran kas. Pebisnis yang terlalu fokus pada laba adalah pebisnis tipe pedagang, sulit berkembang. Sedangkan pebisnis yang cermat, akan menyelaraskan aliran kasnya, mereka ini termasuk tipe pebisnis berjiwa enterpreneur.

4. Incremental cash flows count

Incremental cash flows adalah arus kas yang berhubungan langsung dengan investasi, dimana pengambilan keputusan dilakukan berdasarkan pertimbangan adanya pertambahan kas jika suatu proyek dikerjakan, ataupun mempertimbangkan dampak yang terjadi terhadap kondisi keuangan (kas) saat proyek diterima dan pada saat proyek tidak diterima untuk dikerjakan.

\section{The curse of competitive markets}

Persaingan yang semakin ketat akan membelah pasar menjadi bagian-bagian kecil karena semakin banyaknya produsen yang masuk untuk bersaing pada produk yang sama di pasar yang sama sehingga mengakibatkan lesunya usaha. Kondisi ini mengisyaratkan bahwa tidak selamanya laba dapat diperoleh dalam jumlah yang besar. Kecilnya penerimaan laba akan berdampak pada kecilnya tingkat pengembalian investasi. Untuk itu perlu dilakukan beberapa hal untuk menjaga agar usaha tetap mampu bersaing dan mempertahankan pasarnya, diantaranya adalah diversifikasi produk, penguasaan bahan baku, penggunaan teknologi tepat guna untuk meminimalisir biaya.

6. Efficient capital markets

Capital market atau pasar modal yang efesien adalah pasar modal dimana perusahaan memiliki gerak yang cepat dan harga yang tepat pula. aktiva financial yang diperjual belikan mencerminkan seluruh informasi yang ada dan dapat 
menyesuaikan diri secara cepat terhadap informasi baru. Efisiensi pasar modal dinilai melalui keberhasilannya dalam menggabungkan dan menyelaraskan informasi.

\section{The agency problem}

Masalah keagenan terjadi antara para manajer dengan pemegang saham, dimana para manajer dipercaya untuk mengelola perusahaan dan memberikan keuntungan dari semua aktifitas bisnis perusahaan agar para pemegang saham mendapatkan keuntungan dari keuntungan perusahaan tersebut.

\section{Taxes bias business decisions}

Yaitu pertimbangan pajak yang dijadikan landasan pengambilan keputusan terhadap suatu aktifitas bisnis. Untuk itu yang perlu diperhatikan dalam manajemen keuangan adalah, segala keputusan dan perhitungan haruslah setelah dipotong pajak. Artinya jangan hanya melihat harga dari suatu produk yang dapat diterapkan pada sebuah wilayah lebih menguntungkan, tetapi lupa bahwa harga tersebut belum dimasukkan komponen pajak.

9. All risk is not equal

Setiap usaha memiliki resiko yang berbeda, untuk itu perlu melakukan investasi usaha pada bidang-bidang yang berbeda untuk mengantisipasi terjadinya resiko yang mengakibatkan collaps nya sebuah usaha.

\section{Ethical dilemmas are everywhere in finance}

Etika merupakan nilai-nilai normatif yang harus dilekatkan pada sikap seseorang dimanapun dia berada. Namun demikian, sering terjadi dilema di tengah-tengah aktifitas bisnis yang dilakukan. Hal ini karena adanya kepentingan-kepentingan tertentu pada setiap diri individu. Untuk itu, pada setiap perusahaan selalu ada aturan nilai 'universal' yang sering disebut Budaya Perusahaan sebagai bentuk dan upaya perusahaan mengarahkan karyawannya agar memegang teguh nilai-nilai yang baik

\section{HIPOTESIS}

Hipotsis memberikan keterangan sementara mengenai fenomena yang diteliti, dalam hal ini adalah hubungan antara variabel bebas dengan variabel terikat. Maka dapat dirumuskan hipotesisnya sebagai berikut :

\section{Hipotesis Uji Secara Simultan}

Pengujian ini merupakan pengujian yang dilakukan untuk mengetahui apakah variabel bebas secara simultan mempunyai pengaruh yang signifikan terhadap variabel terikat.

H01 : $\beta \leq 0=\mathrm{KI}$, DER, dan ROA diduga tidak berpengaruh terhadap nilai perusahaan.

Ha1 : $\beta>0=\mathrm{KI}$, DER, dan ROA diduga berpengaruh terhadap nilai perusahaan.

\section{Hipotesis Uji Secara Parsial}

Pengujian ini dilakukan untuk menguji apakah setiap variabel bebas mempunyai pengaruh yang signifikan terhadap variabel terikat. 
H02: $\beta \leq 0=$ Kepemilikan institusional diduga tidak berpengaruh terhadap nilai perusahaan.

Ha2 $: \beta>0=$ Kepemilikan institusional diduga berpengaruh terhadap nilai perusahaan.

H03 : $\beta \leq 0=$ Struktur modal diduga tidak berpengaruh terhadap nilai perusahaan .

Ha3 $: \beta>0=$ Struktur modal diduga berpengaruh terhadap nilai perusahaan.

H04 : $\beta \leq 0=$ Profitabilitas diduga tidak berpengaruh terhadap nilai perusahaan.

Ha4 : $\beta>0=$ Profitabilitas diduga berpengaruh terhadap nilai perusahaan.

\section{HASIL PENELITIAN}

\section{Analisis Deskriptif}

Analisa deskriptif bertujuan untuk memberikan gambaran tentang data yang digunakan dalam penelitian ini. Data terlebih dahulu ditinjau mengenai deskripsi variabel penilaian dengan analisis statistik deskriptif. Statistik deskriptif dapat dilihat nilai minimum, maksimum, nilai ratarata (mean), dan standar deviasi.

Tabel 4.2

\section{Ringkasan Hasil Deskriptif}

\section{Descriptive Statistics}

\begin{tabular}{|c|c|c|c|c|c|}
\hline & $\mathrm{N}$ & Minimum & Maximum & Mean & Std. Deviation \\
\hline PBV & 66 & .15000 & .93000 & .5360606 & .22267519 \\
\hline Ln_KI & 66 & 3.71 & 4.54 & 4.2284 & .20184 \\
\hline DER & 66 & .12000 & 2.12000 & .8972727 & .48391209 \\
\hline ROA & 66 & -6.87000 & 9.56000 & 2.0859091 & 3.27680331 \\
\hline $\begin{array}{ll}\text { Valid } & \mathrm{N} \\
\text { (listwise) } & \end{array}$ & 66 & & & & \\
\hline
\end{tabular}

\section{Uji Normalitas Residual}

Pengujian ini dilakukan untuk mendeteksi apakah data berdistribusi normal atau tidak mengunakan Uji Normal p-plot of regression standardized residual dependent $Y$ serta uji Kolmogorov sebagai berikut : 


\section{Gambar 4.1 \\ Hasil Uji Normal P-P Plot of Regression Standardized Residual}

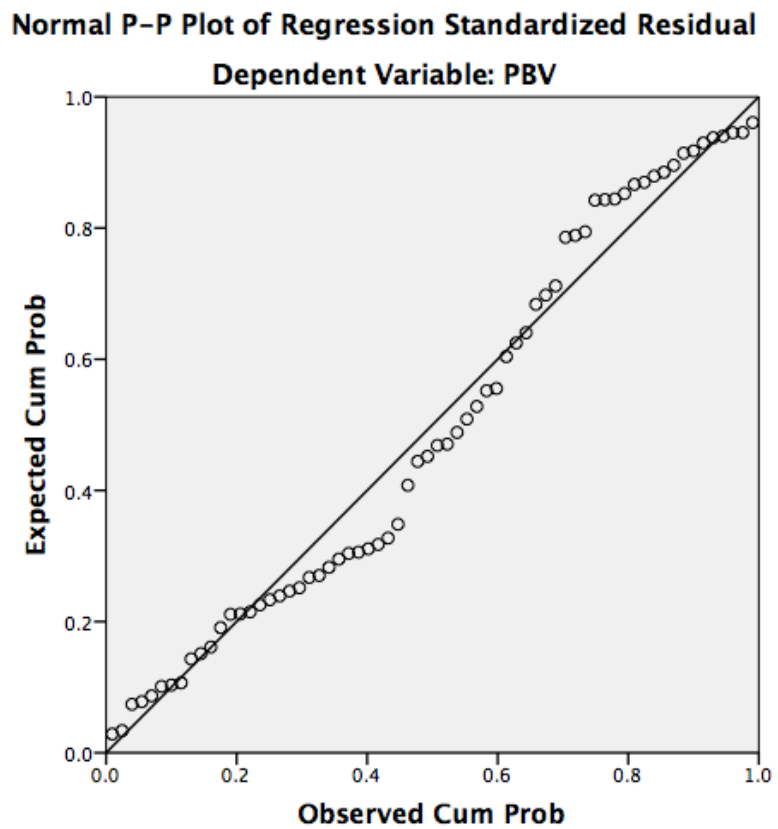

Tabel 4.3

Hasil Uji One-Sample Kolmogorov-Smirnov Test

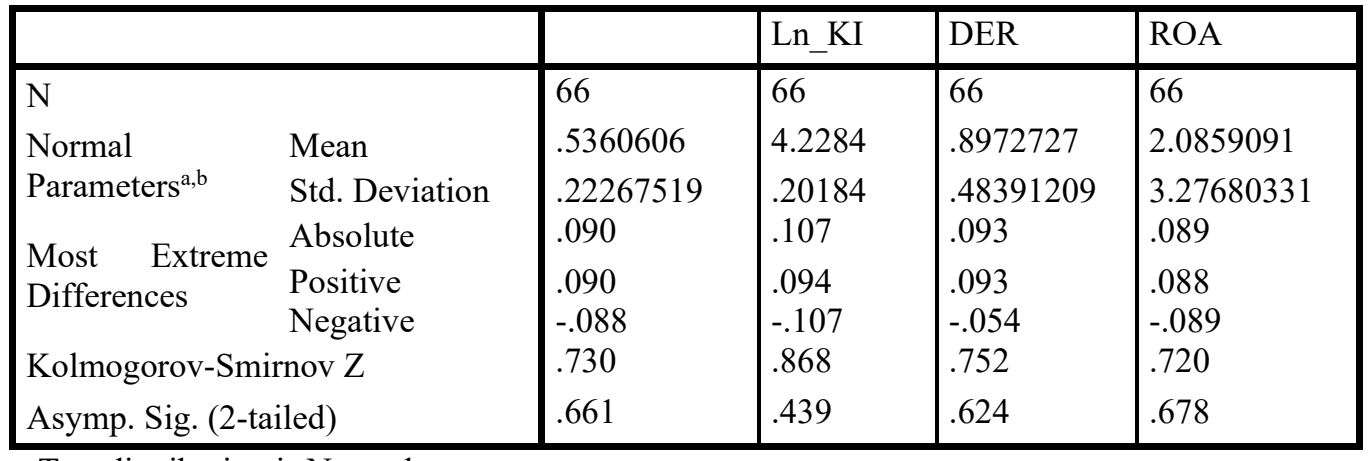

a. Test distribution is Normal.

b. Calculated from data.

\section{UJI ASUMSI KLASIK}

\section{Hasil Uji Multikolinieritas}

Uji multikolinieritas ini bertujuan untuk menguji apakah model regresi ditemukan adanya hubungan antara variabel bebas. Berdasarkan nilai Tolerance, nilai yang terbentuk harus di atas 0,10 dan bila menggunakan VIF, nilai yang terbentuk harus diantara 1 sampai dengan 10 $(1-10)$. 
Tabel 4.4

\section{Hasil Uji Multikolinieritas}

\begin{tabular}{|ll|l|l|}
\hline \multirow{2}{*}{ Model } & \multicolumn{2}{|l|}{ Collinearity Statistics } \\
\cline { 2 - 4 } & Tolerance & VIF \\
\hline $1 \quad$ (Constant) & & \\
& KI & .958 & 1.044 \\
DER & .919 & 1.089 \\
ROA & .921 & 1.086 \\
\hline
\end{tabular}

Sumber: Data diolah dengan SPSS 21

\section{Uji Autokorelasi}

Penyimpanagn autokorelasi dalam penelitian diuji dengan uji Durbin Watson (DW).

Berdasarkan output SPSS, berikut adalah nilai Durbin Watson.

\section{Tabel 4.5}

\section{Model Summary \\ Hasil Uji Autokorelasi}

\begin{tabular}{|l|l|}
\hline Model & Durbin-Watson \\
\hline 1 & 2.214 \\
\hline
\end{tabular}

\section{Uji Heteroskedastisitas}

Deteksi ada tidaknya heteroskedastisitas dapat dilakukan dengan melihat ada tidaknya pola tertentu pada grafik scatterplot. Berikut ini merupakan hasil uji heteroskedastisitas.

\section{Gambar 4.2}

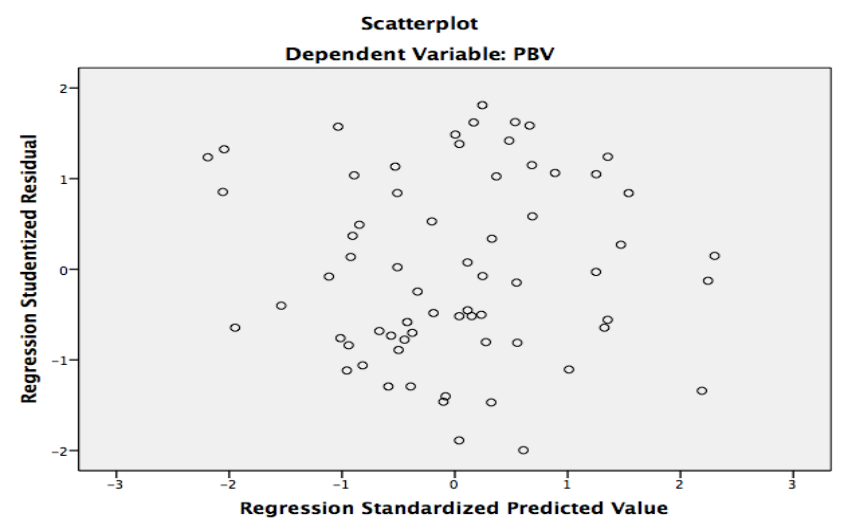




\section{Uji Regresi Berganda}

1. Hasil Uji F (Uji Simultan)

Hasil dari nilai $F$ hitung dan taraf signifikansinya sbb :

Tabel 4.6

Hasil Uji Simultan (Uji F)

ANOVA $^{\mathrm{a}}$

\begin{tabular}{|l|l|l|l|l|l|}
\hline Model & $\begin{array}{l}\text { Sum of } \\
\text { Squares }\end{array}$ & df & Mean Square & F & Sig. \\
\hline Regression & .416 & 3 & .139 & 3.065 & $.034^{\mathrm{b}}$ \\
$\begin{array}{l}1 \text { Residual } \\
\text { Total }\end{array}$ & 2.807 & 62 & .045 & & \\
\hline
\end{tabular}

a. Dependent Variable: PBV

b. Predictors: (Constant), ROA, Ln_KI, DER

2. Hasil Uji t (Uji Parsial)

Hasil perhitungan nilai t hitung dan taraf signifikansinya sbb :

Tabel 4.7

Coefficients $^{\mathrm{a}}$

\section{Hasil Uji Parsial (Uji t)}

\begin{tabular}{|l|l|l|l|l|l|}
\hline \multirow{2}{*}{ Model } & \multicolumn{2}{|l|}{$\begin{array}{l}\text { Unstandardized } \\
\text { Coefficients }\end{array}$} & $\begin{array}{l}\text { Standardized } \\
\text { Coefficients }\end{array}$ & $\mathrm{t}$ & \multirow{2}{*}{ Sig. } \\
\cline { 2 - 4 } & $\mathrm{B}$ & Std. Error & Beta & & \\
\hline (Constant) & 1.071 & .573 & & 1.869 & .066 \\
Ln_KI & -.118 & .134 & -.107 & -.886 & .379 \\
DER & -.082 & .057 & -.178 & -1.438 & .155 \\
ROA & .019 & .008 & .277 & 2.241 & .029 \\
\hline
\end{tabular}

a. Dependent Variable: PBV

3. Hasil Uji Koefisiensi Determinasi $\left(\mathbf{R}^{2}\right)$

Pengaruh variabel bebas secara simultan terhadap variabel terikat berdasarkan R-Square sebagai berikut:

Tabel 4.8

Model Summary ${ }^{\mathrm{b}}$

\section{Hasil R-Square}

\begin{tabular}{|l|l|l|l|l|}
\hline Model & R & R Square & Adjusted R Square & $\begin{array}{l}\text { Std. Error of the } \\
\text { Estimate }\end{array}$ \\
\hline 1 & $.359^{\mathrm{a}}$ & .129 & .087 & .21276531 \\
\hline
\end{tabular}

a. Predictors: (Constant), ROA, Ln_KI, DER

b. Dependent Variable PBV 


\section{Persamaan Regresi Hasil persamaan regresi terlihat sebagai berikut : Tabel 4.9 Persamaan Regresi}

\section{Coefficients $^{\mathbf{a}}$}

\begin{tabular}{|l|l|l|l|l|l|}
\hline \multirow{2}{*}{ Model } & \multicolumn{2}{|l|}{$\begin{array}{l}\text { Unstandardized } \\
\text { Coefficients }\end{array}$} & $\begin{array}{l}\text { Standardized } \\
\text { Coefficients }\end{array}$ & \multirow{2}{*}{ Sig. } \\
\cline { 2 - 4 } & $\mathrm{B}$ & Std. Error & Beta & & \\
\hline (Constant) & 1.071 & .573 & & 1.869 & .066 \\
Ln_KI & -.118 & .134 & -.107 & -.886 & .379 \\
DER & -.082 & .057 & -.178 & -1.438 & .155 \\
ROA & .019 & .008 & .277 & 2.241 & .029 \\
\hline
\end{tabular}

a. Dependent Variable: PBV

\section{Kesimpulan}

Berdasarkan hasil analisis data mengenai pengaruh Kepemilikan Institusional, Struktur Modal, dan Profitabilitas terhadap Nilai Perusahaan manufaktur yang terdaftar di Bursa Efek Indonesia periode Tahun 2015-2017, dapat disimpulkan bahwa :

1. Variabel independen yaitu Kepemilikan Institusional (KI), Struktur Modal (DER), dan Profitabilitas (ROA) melalui uji F secara simultan atau secara bersama-sama berpengaruh terhadap variabel dependen yaitu Nilai Perusahaan (PBV), hal ini dibuktikan dengan diperolehnya nilai signifikansi sebesar 0,034. Nilai signifikansi KI, DER, dan ROA lebih kecil dari nilai signifikansi yang diharapkan 0,05 menunjukkan bahwa hipotesis H01 ditolak dan Hal diterima, sehingga disimpulkan KI, DER, dan ROA, secara bersamasama berpengaruh terhadap Nilai Perusahaan Manufaktur yang terdaftar di Bursa Efek Indonesia periode Tahun 2015-2017.

2. Kepemilikan Institusional tidak berpengaruh terhadap Nilai Perusahaan (PBV), hal ini dibuktikan dengan diperolehnya nilai koefisien regresi sebesar -0,118 dengan signifikansi 0,379. Nilai signifikansi Kepemilikan Institusional yang lebih besar dari nilai signifikansi yang diharapkan 0,05 menunjukkan bahwa hipotesis H02 dapat diterima, sehingga disimpulkan Kepemilikan Institusional tidak berpengaruh terhadap Nilai Perusahaan pada perusahaan Manufaktur yang terdaftar di Bursa Efek Indonesia periode 2015-2017.

3. Struktur Modal (DER) tidak berpengaruh terhadap Nilai Perusahaan (PBV), hal ini dibuktikan dengan diperolehnya nilai koefisien regresi sebesar -0,082 dengan signifikansi 0,155 . Nilai signifikansi DER yang lebih besar dari nilai signifikansi yang diharapkan 0,05 menunjukkan bahwa hipotesis H03 dapat diterima, sehingga disimpulkan Struktur Modal (DER) tidak berpengaruh terhadap Nilai Perusahaan pada perusahaan Manufaktur yang terdaftar di Bursa Efek Indonesia periode 2015-2017.

4. Profitabilitas (ROA) berpengaruh terhadap Nilai Perusahaan (PBV), hal ini dibuktikan dengan diperolehnya nilai koefisien regresi sebesar 0,019 dengan signifikansi 0,029. Nilai signifikansi ROA lebih kecil dari nilai signifikansi yang diharapkan 0,05 menunjukkan bahwa hipotesis H04 ditolak dan Ha4 diterima, sehingga disimpulkan Profitabilitas (ROA) berpengaruh terhadap Nilai Perusahaan pada perusahaan Manufaktur yang terdaftar di Bursa Efek Indonesia periode 2015-2017. 
5. Hasil penelitian ini menunjukkan bahwa nilai koefisien determinasi (R2) sebesar 0,087 yang berarti variabel independen mempengaruhi variabel dependen sebesar 8,7\% dan sisanya yaitu 91,3\% dipengaruhi oleh variabel lain diluar penelitian ini.

\section{Saran} berikut

Berdasarkan hasil penelitian yang diperoleh, maka saran yang diberikan adalah sebagai

1. Penelitian ini hanya menggunakan 3 variabel sebagai indikator yaitu KI, DER, dan ROA. Dari 3 variabel tersebut hanya satu variabel yaitu ROA yang dapat mempengaruhi Nilai Perusahaan. Oleh sebab itu disarankan untuk peneliti selanjutnya perlu menambah variabel lain yang memungkinkan mempengaruhi Nilai Perusahaan. Karena Adjusted RSquare penelitian ini juga menunjukan presentase yang sangat kecil yaitu sebesar $8,7 \%$ dari variabel perubahan nilai perusahaan dapat dijelaskan oleh variabel independennya, sisanya $91,3 \%$ dipengaruhi oleh variabel lain.

2. Penelitian ini dilakukan pada perusahaan Manufaktur yang terdaftar di Bursa Efek Indonesia periode tahun 2015-2017, untuk penelitian selanjutnya dapat dikembangkan dengan lebih spesifik terhadap sektor perusahaan manufakturnya.

3. Penelitian yang akan datang sebaiknya memperpanjang periode penelitian atau memperbanyak jumlah sampel agar hasil yang diperoleh dapat lebih merefleksikan pergerakan nilai perusahaan di Bursa Efek Indonesia secara historikal

\section{DAFTAR PUSTAKA}

Atmaja, Lukas Setia. 2008. Teori dan Praktik Manajemen Keuangan. Yogyakarta: Penerbit ANDI

Brigham, E. F dan Houston, J.F. 2011. Dasar-dasar Manajemen Keuangan.Diterjemahkan oleh Ali Akbar Yulianto, Buku 2, Edisi 11, Salemba Empat, Jakarta

Husnan. 2000. Manajemen Keuangan Teori dan Penerapan (Keputusan Jangka Panjang, Edisi 4, Buku 1, Yogyakarta.

Imam Gozali. 2001. Aplikasi Analisis Multivariat dengan Program SPSS. Badan Penerbit Unversitas Diponegoro. Semarang.

Kasmir. 2010. Pengantar Manajemen Keuangan. Cetakan Kedua.Jakarta: Kencana

Santoso, Singgih. 2012. Analisis SPSS pada Satatistik Parametrik. Jakarta: PT. Elex Media Komput Indo.

Sudana, I Made. 2011. Manajemen Keuangan Perusahaan: Teori dan Praktek. Jakarta: Erlangga

Sugiarto. 2009. Struktur Modal, Struktur Kepemilikan Perusahaan, Permasalahan, Keagenan dan Informasi Asimetri. Yogyakarta: Graha Ilmu

Sugiyono. 2011. Metode Penelitian Kuantitatif, Kualitatif dan R\&D. Bandung: Alfabeta

Taswan. 2002. Analisis Pengaruh Insider Ownership, Kebijakan Hutang dan Deviden terhadap Nilai Perusahaan serta Faktor-Faktor yang Mempengaruhinya. Yogyakarta: Universitas 
Gadjah Mada

Wirawati. 2008. Pengaruh Faktor Fundamental Perusahaan Terhadap Price To Book Value Dalam Penilaian Saham di Burs Efek Jakarta Dalam Kondisi Krisis Moneter. Buletin Studi Ekonomi. 13(1), 92-101.

\section{Jurnal}

Agnova, V., dan Muid, D., 2015, “Analisis Pengaruh Kepemilikan Manajerial, Profitabilitas, Kesempatan Investasi dan Kebijakan Hutang terhadap Nilai Perusahaan (Studi pada Perusahaan Manufaktur yang Terdaftar di BEI Tahun 2010-2013)". Volume 4, Nomer 4, Tahun 2015.

Christiawan, Yulius Jogi, dan Tarigan, Josua. 2007. Kepemilikan Manajerial : Kebijakan Hutang, Kinerja dan Nilai Perusahaan, Jurnal Akuntansi dan Keuangan Vol 9. No.1 Mei 2007

Diyah, Pujiati, dan Widanar, Erman. 2009. "Pengaruh Struktur Kepemilikan Terhadap Nilai Perusahaan: Keputusan Keuangan sebagai Variabel Intervening." Jurnal Ekonomi Bisnis dan Akuntansi Ventura, Vol. 12. No.1, h. 71-86

Haruman, Tendi. 2008. Pengaruh Struktur Kepemilikan Terhadap Keputusan Keuangan dan Nilai Perusahaan. Simposium Nasional Akuntansi XI, Pontianak.

Octavia, Sally Malva. 2017. Pengaruh Kepemilikan Manajerial dan Kepemilikan Institusional terhadap Niai Perusahaan (Studi pada Perusahaan Manufaktur yang Terdaftar di BEI Tahun 2009-2015). Skripsi.

Samisi, Komang. 2013. Pengaruh Struktur Pendanaan Terhadap Nilai Perusahaan dengan Kepemilikan Manajerial Sebagai Variabel Moderasi. E-Journal Universitas Udayana. Vol. 5, No. 2. pp. 451-469.

Sasurya, Aris dan Asandimitra, Nadia. 2013. Pengaruh Kepemilikan Manajerial, Keputusan Investasi, Keputusan Pendanaan, dan Kebijakan Dividen Terhadap Nilai Perusahaan. Jurnal Ilmu Manajemen. Vol.1 No.2. pp. 428-442

Sujoko dan Subyantoro, Ugy. 2007. Pengaruh Struktur Kepemilikan Saham, Leverage, Faktor Intern dan Faktor Ekstern Terhadap Nilai Perusahaan. Jurnal Manajemen dan Kewirausahaan. Vol. 9 No.1. Maret 2007. pp. 41-48 